\author{
Dr Toma Birmontiene, * \\ Judge of the Constitutional Court of the Republic of Lithuania \\ Professor, Mykolas Romeris University, Lithuania
}

PREŠTAMPAN RAD

\title{
THE CHALLENGES FACED BY THE CONSTITUTIONAL COURT OF LITHUANIA DURING THE GLOBAL ECONOMIC CRISIS ${ }^{* *}$
}

\begin{abstract}
Техничком грешком рад ауторке T. Birmontienė “THE CHALLENGES FACED BY THE CONSTITUTIONAL COURT OF LITHUANIA DURING THE GLOBAL CONOMIC CRISIS", објављен у Зборнику радова Правног факултета у Нишу бр. 69 2015. стр. 29-55, категорисан је као НАУЧНИ ЧЛАНАК уместо напомене да је ПРЕШТАМПАН РАД. Мада је Редакција часописа јасно у фус ноти нагласила да је рад објављен у публикацији Уставног суда Србије и изложен на Конференцији поводом годишњице рада Уставног суда октобра 2013. године, ради се о техничком пропусту приликом припреме броја.
\end{abstract}

Due to a technical error, the article authored by T. Birmontienè "THE CHALLENGES FACED BY THE CONSTITUTIONAL COURT OF LITHUANIA DURING THE GLOBAL CONOMIC CRISIS", published in the Proceedings of the Law Faculty in Nis, br. 69. 2015. str. 29-55, was categorized as a Scientific Article instead of being designated as a Reprint. Although the Editorial Board of the Law Faculty Journal clearly noted in the footnote that the paper was previously published in the monograph of the Constitutional Court of Serbia and presented at the Conference held in October 2013, on the occasion of the anniversary of the Constitutional Court of Serbia, hereby we acknowedge for the technical error that occurred in preparing that issue of the Law Faculty Journal for publication.

\footnotetext{
*t.birmontiene@1rkt.lt

** This paper is presented at the International Conference „The Position and Perspective of Constitutional Justice“, Belgrade, 16-18 October 2013. and published in the Conference Publication, Belgrade, 2014, pp. 419-444.
} 